\title{
LABORATORY PRODUCTION OF ALCOHOL FROM RICE AND MAIZE CHAFFS
}

F. O. AGBOOLA AND A. I. RAJI

(Received 22 September 2010; Revision Accepted 20 April 2012)

\begin{abstract}
Alcohol fermentation of two agricultural wastes (rice husk from rice (Oryza satira) and cobs of maize (zea mays) were converted to fermentable sugar by hydrolysis with two cellulase enzyme producing fungi - Aspergillus niger and Penicillium digitatum. The agricultural chaffs used were dilignified by combined alkaline and steam pretreatments to enhance sugar production by the organisms. The reducing sugar produced from the chaffs were fermented to alcohol using baker's yeast (Saccharomyces cerevisiae). The alcohol content of the samples were determined by distillation method. The concentration of alcohol content in MSRH and MSCC ranges between $126.5 \mathrm{mg} / \mathrm{ml}-479.3 \mathrm{mg} / \mathrm{ml}$ and $331.6 \mathrm{mg} / \mathrm{ml}-521.1 \mathrm{mg} / \mathrm{ml}$ respectively by $A$. niger and Penicillium digitatum. The highest reducing sugar obtained from MSCC medium degraded by $A$. niger and $P$. digitatum were $1560 \times 10^{3} \mathrm{mg} / \mathrm{ml}$ and $1,300 \times 10^{3} \mathrm{mg} / \mathrm{ml}$ respectively. The results of this research work highlight the industrial potentials of these agricultural chaffs as substrates for alcohol production.
\end{abstract}

KEYWORDS: Chaffs, oryzae sativa, zea mays, fermentation, alcohol, Aspergillus, Penicillium.

\section{INTRODUCTION}

Alcohol is an important industrial chemical. It is one of the product of yeast metabolism. The production of alcohol by fermentation is an ancient act and is often considered to be one of the first microbial process used by man. Production of industrial alcohol by fermentation draws heavily upon the accumulated knowledge of the brewer and distiller. Alcohol is a chemical substance with molecular formular $\mathrm{C}_{2} \mathrm{H}_{5} \mathrm{OH}(\mathrm{ROH})$ containing only carbon, hydrogen and oxygen and the molecular mass is 46 .

Alcohol is produced from sugar containing materials such as starch, molasses by a fermentation process utilizing yeast to convert the sugar to alcohol (Brien and Craig, 1996). The most widely used raw materials is blackstrap molasses. This is the waste syrup (mother liquor) remaining after the extraction of crystallized sugar from the evaporated sugar cane juice obtained in commercial cane - sugar mill - operations (Palmer, 1989). Alcohol is also produced by fermentation of starch and sulphite waste liquor, via the ethylsulphate route; by the direct hydration of ethylene; and from various grains and agricultural products (Lyons et al; 1995). Alcohol of appreciable yield had been produced from both cellulose and lignocellulose materials using special yeast strain called Pnachysolen tannophillus for fermentation (Lynd, 1990). Lee et al; (1987) produced alcohol from sargo starch using mobilized amyloglucosidase and zymomonas mobilis. The success of various cellutolisic and starchy materials for alcohol production depends on the development of pre-treatment procedures and highly effective enzymic system for conversion of pre-treated material for fermentable sugars (Agboola, 2006; 2009). Alcohol is a clear, colourless, flammable liquid miscible with water and many organic solvent in all ratio.

\section{Economic Importance of Alcohol and the Nigeria Situation}

The industrial uses of alcohol are generally on the increase. It enjoys wide application in the chemical industry as a chemical feed stock. Alcohol serves as an intermediate in many chemical processes due to its great reactivity. For example, it serves as a raw material in chemical manufacture like glycol-ethers, ethylchloride, amines, ethyl acetate, vinegar, acetic acid and in the production of acetaldehyde. Alcohol is also widely used in industry as a solvent for dyes, oils, waxes, explosives and cosmetics. It serves as a disinfectant in hospitals for cleaning and lighting in the home and in the laboratory second only to water as a solvent. Alcohol is mixed with petrol or gasoline up to $10 \%$ and this is called gasohol and used in automobile.

Due to usefulness of alcohol in Nigeria over abundant agricultural chaffs and wastes can be used to produce alcohol which can be exported to gain foreign reserve. Thus, also controlling the environmental pollution currently experienced all over the country by these useful agricultural and domestic wastes. In chemical and pharmaceutical industries, alcohol has prospective application which are found all over Nigeria. As energy cost increases and petrochemical raw materials become scarce, production of alcohol from agricultural waste materials could become a viable alternative (Dominguez et al; 2000).

Following the realization of the great economic importance of alcohol in the nation and throughout the world, this study was undertaken to examine the method of producing alcohol under laboratory conditions using

F. O. Agboola, Department of Biology, Institute of Basic and Applied Sciences, Kwara State Polytechnic, P.M.B. 1375, llorin. Nigeria.

A. I. Raji, Department of Micro-Biology, University of Ilorin, Ilorin. Nigeria. 
some selected agricultural chaffs; with the aim of determining the role of microorganisms in the production process. Corn and rice chaffs were possible substrates for alcohol production using Aspergillus niger $\left(\mathrm{Cs}_{9}\right)$ and Penicillium digitatum $\left(\mathrm{YF}_{50}\right)$ for degradation and Saccharomyces cerevisiae for fermentation to yield alcohol. These agricultural chaffs are thus converted to useful products as well as achieve environmental pollution control of these chaffs. Local production of alcohol using these agricultural chaffs would certainly help to conserve foreign exchange and probably help in increasing local contents indigenous industries.

\section{MATERIALS AND METHODS \\ Sample Collection}

The rice and corn chaffs used in this work were collected from Ipata Market in Kwara State.

\section{Sources of Organisms}

Aspergillus niger and Penicillium digitatum were isolated from yam flour and compost soil. They were maintained on Potato dextrose Agar (PDA) slants and kept at $4^{0} \mathrm{C}$ prior to use. The baker's yeast was obtained from Baboko market in llorin.

\section{Sample Treatment}

The pretreatment of substrates was carried out in the laboratory. The methods of Ali et al (1991) and Lyons, et al (1995) were adopted. Rice husk was sorted to remove stones and washed thoroughly with water to remove surface dust. It was dried and ground with domestic blender. (250W Philips Holland). Corn cob was sun dried and chopped into pieces and was ground into pellets.

\section{Combined Alkaline and Steam Pretreatment}

The ground rice husk and corn cob were autoclaved at $121^{\circ} \mathrm{C}$ with $5 \%(\mathrm{~W} / \mathrm{V}) \mathrm{NaOH}(20 \mathrm{ml}$ per gramme of substrate) in separate conical flasks for degradation. The autoclaved materials were filtered through muslin cloth and the substrates washed thoroughly with water and neutralized with dilute $\mathrm{HCl}$ to $\mathrm{pH} 7$ and finally washed with distilled water and dried at $80^{\circ} \mathrm{C}$.

Corn chaff or corn cob used in this study is referred to the cobs left after removal of the maize fruits. Rice chaff means rice husks. This method generally involved the alkaline and steam pre-treatments of the substrates.

\section{RICE CHAFF}

Rice chaff was sorted to remove stones and washed thoroughly with water to remove surface dust. It was then dried and ground with domestic blender (250W Philips Holland).

\section{CORN CHAFF} and was ground.

Corn chaff was sun dried, chopped into pieces

\section{COMBINED ALKALINE AND STEAM PRE- TREATMENT}

The ground rice chaff and corn chaff were autoclaved at $121^{\circ} \mathrm{C}$ with $5 \%$ (W/V) $\mathrm{NaOH}(20 \mathrm{ml}$ per gramme of substrate) in separate conical flasks for degradation. The autoclaved materials were filtered through muslin cloth and the substrates washed thoroughly with water and neutralized with dilute $\mathrm{HCl}$ to $\mathrm{PH}$ 7. The substrates were finally washed with distilled water and dried at $80^{\circ} \mathrm{C}$.

\section{MEDIA (MSRC): Mineral - Salts Rice Chaff Medium}

Mineral salts - rice chaff medium containing (g/L) $\mathrm{KH}_{2} \mathrm{PO}_{4}, 10.0 ;\left(\mathrm{NH}_{4}\right)_{2} \mathrm{SO}_{4}, 10.5 ; \mathrm{MgSO}_{4} .7 \mathrm{H}_{2} 0,0.3$. $\mathrm{CaCl}_{2}, 0.5 ; \mathrm{FeSO}_{4} .7 \mathrm{H}_{2} \mathrm{O}, 0.013 ; \mathrm{MnSO}_{4} . \mathrm{H}_{2} \mathrm{O}, 0.004$; $\mathrm{Z}_{\mathrm{n}} \mathrm{SO}_{4} .7 \mathrm{H}_{2} \mathrm{O}, 0.004 ; \mathrm{CaCl}_{2} .6 \mathrm{H}_{2} \mathrm{O}, 0.0067$; Yeast extract, 0.5 , rice chaff powder, 40.0 .

\section{MINERAL SALTS CORN CHAFF MEDIUM (CCM)}

Mineral salts-corn chaff medium containing $(\mathrm{g} / \mathrm{L})$, $\mathrm{KH}_{2} \mathrm{PO} 4,10.0 ;\left(\mathrm{NH}_{4}\right)_{2} \mathrm{SO}_{4}, 10.5 ; \mathrm{MgSO}_{4} .7 \mathrm{H}_{2} \mathrm{O} .0 .013$; $\mathrm{MnSO}_{4} \cdot \mathrm{H}_{2} \mathrm{O}, 0.004$;

$\mathrm{ZnSO}_{4} .7 \mathrm{H}_{2} \mathrm{O}, 0.004 ; \mathrm{CaCl}_{2} \cdot 6 \mathrm{H}_{2} 0,0.0067$; Yeast extract, 0.5 , Corn chaff powder, 40.0 .

\section{Cultural Condition for Reducing Sugar Production}

A modified method of Sanni et al; (1992) was used in which spores of 48 hours old cultures of Aspergillus niger $\left(\mathrm{CS}_{9}\right)$ and Penicillium digitatum $\left(\mathrm{YF}_{50}\right)$ were harvested by washing slants with $10 \mathrm{ml}$ of sterile distilled water. An aliquot of $1.5 \mathrm{ml}$ of spores suspension was inoculated into $150 \mathrm{ml}$ of each of MSRC and MSCC medium and incubated at $28^{\circ} \mathrm{C}$ in an orbital shaker maker set at 100rpm.

\section{Assay for Reducing Sugar Production}

Reducing sugar production was determined colorimetrically by measuring the increase in reducing groups in the culture media (Miller, 1959). Cultured samples were centrifugal at $3,000 \mathrm{rpm}$ for 15 minutes to remove the mycelia and the supernatant fluid used to assay for reducing sugar. The same volume of the supernant and the dinitrosalicylic acid reagent $(1.5 \mathrm{ml})$ were measured out and added together inside the test tube. The blank was prepared by adding equal volume of dinitrosalicylic acid reagent and distilled water $(1.5 \mathrm{ml})$. The mixture was heated in boiling water bath for 15 minutes and then cooled under running tap water at ambient temperature. The resulting orange coloured solution was decanted into colorimeter tubes and absorbance was read at $575 \mathrm{~nm}$ using a spectrophotometer (MILTON ROY COMPANY SPECTRONIC - 20D).

\section{pH Determination}

$\mathrm{pH}$ was determined using a $\mathrm{pH}$ meter (PYE ELECTRONIC INSTRUMENT LTD.).

\section{Preparation of Yeast Solution}

Yeast solution was prepared by dissolving 20 gramme of the dry baker's yeast in $100 \mathrm{ml}$ of distilled warm water and kept for 15 minutes prior to use. $15 \%$ $(22.5 \mathrm{ml})$ was inoculated into $150 \mathrm{ml}$ of fermented wort. The control experiment was void of yeast inoculum.

\section{Fermentation}

The supernatant of the fermentation product of MSRC and MSCC was used as medium for yeast fermentation. One hundred and twenty millimeter (120 $\mathrm{ml}$ ) of each of the worts (Supernant Solution) was 
transferred into the separate flasks (fermentor sodium metabisulphite $20 \%$ was added to eliminate any contaminant. $15 \mathrm{~g} / \mathrm{L} \quad \mathrm{KH}_{2} \mathrm{PO}_{4}, 2 \mathrm{~g} / \mathrm{L} \quad \mathrm{NH}_{4} \mathrm{CL}, \quad 1 \mathrm{gm} / \mathrm{L}$ $\mathrm{NaHPO}_{4}$ and $1 \mathrm{gm} / \mathrm{L}\left(\mathrm{NH}_{4}\right)_{2} \quad \mathrm{NO}_{3}$ was as nitrogen and phosphorus sources (Adeniran and Adeleye, 1994). The worts were then seeded with baker's yeast (Saccharomyces cerevisiae $(22.5 \mathrm{ml})$.

Fermentation was allowed to continue for $5,10,14$, and 20 days at $28^{\circ} \mathrm{C}$. Each fermentor was shaken three times daily to prevent the yeast from settling to the bottom of the wort and to ensure even distribution of nutrients and substrates to the yeast. At the end of the fermentation days, the fermented worts were filtered and the filtrates was distilled by fractional distillation method and the alcohol was collected into clean bottles which were stored for further analysis.

\section{Analysis of Distillates}

A modified method of Pearson (1976) was used to determine alcohol yield (\% W/V) of each distillate using specific gravity bottle at ambient temperature. The alcoholic content of the sample (rice chaff fermented solution and corn chaff fermented solution) were determined by measuring out $100 \mathrm{ml}$ in a volumetric flask at ambient temperature and washed into the distillation flask with $50 \mathrm{ml}$ of distilled water in a distiller. The acidity of each sample were neutralized with $1 \mathrm{ml}$ of sodium hydroxide. The samples were distilled slowly on hot plate at (B.P. $78-80^{\circ} \mathrm{C}$ ) until $50 \mathrm{ml}$ of distillates were collected; cooled and the specific gravity were determined. Their corresponding alcoholic content by volume was obtained from reference table 1 (Pearson, 1976). The control experiment was done by adding $100 \mathrm{ml}$ of water and $50 \mathrm{ml}$ of distilled water into a volumetric flask and the distillation was carried out.

\section{Calculation}

$\begin{array}{lll}\text { Weight of density bottle } & = & \mathrm{ag} \\ \text { Weight of density bottle + water } & = & \mathrm{bg} \\ \text { Weight of density bottle + distillate } & = & \mathrm{cg} \\ \text { Weight of water } & = & \mathrm{b}-\mathrm{a} \\ \text { Weight of distillate from sample } & = & \mathrm{c}-\mathrm{a}\end{array}$

Specific gravity of distillate

$$
\begin{aligned}
& =\frac{\text { Weight of distillate }}{\text { Weight of equal volume of water }} \\
& =\frac{\mathrm{c}-\mathrm{a}}{\mathrm{b}-\mathrm{a}} \text { (Pearson, 1976). }
\end{aligned}
$$

\section{Test for Alcohol (Distillates)}

The method of Murray (1974) was used to confirm the presence of alcohol in the distillate. This was done by using various methods.

First Test: To $2 \mathrm{ml}$ of the distillates, $2 \mathrm{ml}$ of iodine solution (saturated) was added and $1.5 \mathrm{ml}$ of dilute sodium hydroxide solution.

Second Test: About $5 \mathrm{ml}$ of distillates was placed in an evaporating dish and a small piece (about 50mg) of clean freshly cut dry sodium metal was added.

Thirdly: $2 \mathrm{ml}$ of distillates was placed in a petridish and $2 \mathrm{ml}$ of potassium permanganate was added, the mixture was allowed to stay for 15 minutes, then about one gramme of sodium bicarbonate was added.

\section{Determination of Sugar Concentration Preparation of Standard Solution}

Zero point one gramme $(0.1 \mathrm{~g})$ of glucose was dissolved in $100 \mathrm{ml}$ of distilled water. 0.2, 0.4, 0.6, 0.8, $1.0,1.2,1.4,1.6,1.8$ and $2.0 \mathrm{ml}$ of the solution was dispensed into different test tubes. Each solution was then adjusted to $1 \mathrm{ml}$ with corresponding volume of distilled water.

One point five $(1.5 \mathrm{ml})$ of dinitrosalicylic acid reagent was added into each test tube and mixed together, the blank was prepared by adding $1.5 \mathrm{ml}$ of dinitrosalicylic acid reagent to $1.5 \mathrm{ml}$ of distilled water instead of glucose. The mixture was heated in boiling water bath for 15 minutes and then cooled under running tap water at room temperature. The reading obtained was used to plot glucose standard curve.

\section{RESULTS}

From the study, highest concentration of reducing sugar and alcohol were obtained from mineral salt corn cob (MSCC) medium degraded by $A$. niger cs 9 $\left(1560 \times 10^{3} \mathrm{mg} / \mathrm{ml}\right)$ table $5,(696 \mathrm{mg} / \mathrm{ml})$ table 2 . This was followed by mineral salt corn cob medium degraded by $P$. digitatum $\mathrm{yF}_{50}\left(1300 \times 10^{3} \mathrm{mg} / \mathrm{ml}\right)$ table 5 , $(653.8 \mathrm{mg} / \mathrm{ml})$ table 2 .

Therefore, the concentration of alcohol content in MSRH and MSCC were $(126.5-479.3 \mathrm{mg} / \mathrm{ml}) ;(331-$ $521 \mathrm{mg} / \mathrm{ml}) ;(384.2-696.0 \mathrm{mg} / \mathrm{ml})$ and $(331.6-653.8$ $\mathrm{mg} / \mathrm{ml}$ ) respectively. 
Table 1: Concentration of alcohol by S. Cerevisiae in MSRH.

\begin{tabular}{|l|l|l|}
\hline DAYS & $\begin{array}{l}\text { MSRH WORT FROM } \\
\text { A. niger } C s_{9}(\mathrm{mg} / \mathrm{ml})\end{array}$ & $\begin{array}{l}\text { MSRH WORT FROM } \\
\text { P. digitatum YF }\end{array} F_{50}(\mathrm{mg} / \mathrm{ml})$ \\
\hline 5 & 126.5 & $331.6(\mathrm{mg} / \mathrm{ml})$ \\
10 & 413.1 & $521.1(\mathrm{mg} / \mathrm{ml})$ \\
14 & 479.3 & $521.1(\mathrm{mg} / \mathrm{ml})$ \\
20 & 479.3 & $479.3(\mathrm{mg} / \mathrm{ml})$ \\
\hline
\end{tabular}

MSRH $=$ Mineral Salt Rice Husk.

Table 2: Concentration of Alcohol by S. Cerevisiae in MSCC $(\mathrm{mg} / \mathrm{ml})$.

\begin{tabular}{|l|l|l|}
\hline DAYS & $\begin{array}{l}\text { MSCC WORT FROM } \\
\text { A. niger } C s_{9}(\mathrm{mg} / \mathrm{ml})\end{array}$ & $\begin{array}{l}\text { MSCC WORT FROM } \\
\text { P. digitatum } Y F_{50}(\mathrm{mg} / \mathrm{ml})\end{array}$ \\
\hline 5 & 384.2 & 331.6 \\
10 & 653.8 & 568.0 \\
14 & 696.0 & 653.8 \\
20 & 272.5 & 331.6 \\
\hline
\end{tabular}

MSCC $=$ Mineral Salt Corn Cob.

Table 3: Test for Alcohol

\begin{tabular}{|l|l|l|}
\hline TEST & OBSERVATION & INFERENCE \\
\hline $\begin{array}{l}2 \mathrm{ml} \mathrm{of} \mathrm{distillate} \mathrm{+2ml} \mathrm{of} \\
\text { iodine solution }+1.5 \mathrm{ml} \text { of } \\
\text { dilute } \mathrm{NaOH}\end{array}$ & $\begin{array}{l}\text { Decolourization of the } \\
\text { mixture } \\
\text { Colourless }\end{array}$ & Alcohol is suspected \\
\hline $\begin{array}{l}5 \mathrm{ml} \text { of distillate }+ \text { clean } \\
\text { freshly cut dry sodium metal }\end{array}$ & $\begin{array}{l}\text { Colourless and } \\
\text { produced characteristic } \\
\text { odour. }\end{array}$ & Alcohol is suspected. \\
\hline $\begin{array}{l}2 \mathrm{ml} \text { of Acid Permanganate }+ \\
2 \mathrm{ml} \text { of Distillate }\end{array}$ & $\begin{array}{l}\text { Changing from purple colour } \\
\text { to colourless. }\end{array}$ & Alcohol is confirmed. \\
\hline $\begin{array}{l}2 \mathrm{ml} \text { of Distillate }+2 \mathrm{ml} \text { of } \\
\text { Potassium dichromate. }\end{array}$ & $\begin{array}{l}\text { Turned from orange colour to } \\
\text { green colour. }\end{array}$ & Alcohol is confirmed. \\
\hline
\end{tabular}

From this results, only chemical methods were employed to test the alcohol at the end of distillation. Further work needs to be carried out using other confirmatory methods.

The use of baker's yeast instead of yeast isolated from natural source did not have negative effect on the result. The percentage of alcohol obtained in this study was similar to that of other researchers who isolated the yeast from natural sources and that is to confirm the efficacy of the baker's yeast.

Table 4: The yield of reducing sugar in $\mathrm{mg} / \mathrm{ml}$ from fermentation of rice husk/chaff.

\begin{tabular}{|l|l|l|}
\hline Hours & $\begin{array}{l}\text { Concentration of reducing sugar } \\
\text { from MSRH by A. niger }(\mathrm{mg} / \mathrm{ml})\end{array}$ & $\begin{array}{l}\text { Concentration of reducing } \\
\text { sugar from MSRH by } \\
\text { P. digitatum }(\mathrm{mg} / \mathrm{ml})\end{array}$ \\
\hline 0 & 0 & 0 \\
24 & $120 \times 10^{3}$ & $100 \times 10^{3}$ \\
48 & $310 \times 10^{3}$ & $480 \times 10^{3}$ \\
72 & $500 \times 10^{3}$ & $520 \times 10^{3}$ \\
96 & $890 \times 10^{3}$ & $780 \times 10^{3}$ \\
120 & $890 \times 10^{3}$ & $520 \times 10^{3}$ \\
144 & $530 \times 10^{3}$ & $400 \times 10^{3}$ \\
168 & $410 \times 10^{3}$ & $360 \times 10^{3}$ \\
192 & $400 \times 10^{3}$ & $350 \times 10^{3}$ \\
216 & $400 \times 10^{3}$ & $310 \times 10^{3}$ \\
\hline
\end{tabular}


Table 5: The yield of reducing sugar in $\mathrm{mg} / \mathrm{ml}$ from fermentation of corn cob/chaff.

\begin{tabular}{|l|l|l|}
\hline Hours & $\begin{array}{l}\text { Concentration of reducing sugar } \\
\text { from MSCC by A. niger }(\mathrm{mg} / \mathrm{ml})\end{array}$ & $\begin{array}{l}\text { Concentration of reducing } \\
\text { sugar from MSCC by } \\
\text { P. digitatum }(\mathrm{mg} / \mathrm{ml})\end{array}$ \\
\hline 0 & 0 & 0 \\
24 & $430 \times 10^{3}$ & $390 \times 10^{3}$ \\
48 & $650 \times 10^{3}$ & $410 \times 10^{3}$ \\
72 & $960 \times 10^{3}$ & $450 \times 10^{3}$ \\
96 & $1560 \times 10^{3}$ & $1300 \times 10^{3}$ \\
120 & $800 \times 10^{3}$ & $1000 \times 10^{3}$ \\
144 & $680 \times 10^{3}$ & $820 \times 10^{3}$ \\
168 & $630 \times 10^{3}$ & $400 \times 10^{3}$ \\
192 & $450 \times 10^{3}$ & $400 \times 10^{3}$ \\
216 & $350 \times 10^{3}$ & $400 \times 10^{3}$ \\
\hline
\end{tabular}

\section{DISCUSSION}

This study was carried out to determine the potential use of rice chaff and corn chaff (i.e. rice husk corn cob) (that are agricultural waste products) as substrates for alcohol production using $\mathrm{A}$. niger $\mathrm{Cs}_{9}$ and Penicillium digitatum $\mathrm{YF}_{50}$ for degradation. The effectiveness of the chemical that was used for hydrolysis and the enzymes (cellulose) produced into the medium by these fungi resulted into the production of reducing sugar that was used for alcohol production. This was similar to the report of Lyons et al; 1995 . This was also favourably compared with the report of Gharpuray et al; (1983) who stated that alkaline treatment permits greater accessibility of the cellulose to cellulolytic enzyme. The blending of the chaffs used was to increase the accessibility of the substrate to the organisms. This was similar to the observation of Doppelbauer et al (1987) who reported similarly that increase in enzyme production that resulted in increase in fermentable sugar production could be attributable to increase in surface area, pore size, and altered physical nature of lignin. Maheswari et al (1993) and Agboola (2009) reported similar cases.

The high concentration of sugar produced in the medium by the fungi was in line with what Marjailmen et al; (1997) and Agboola (2006) observed that high levels of enzymes and reducing sugar were produced in the medium containing cellulose or complex plant material degraded by fungi. The presence of water in the fermented substrates was important and it was an indication of occurrence of continued active fermentation, this supported the findings of Ullah et al; (1994). The low sugar concentration after optimum was in line with what Brien and Craig (1996) observed.

The alcohol yield (\% W/V) was outlined in the table 1 and 2 and it was found to vary. The high level of alcohol production from these substrates were similar to those that was reported by other researchers on yeast fermentation of starchy and agricultural materials. Adeniran and Adeleye (1994) reported that about $96.17 \%$ alcohol (W/V) was distillated from the fermentation of potato mash by yeast. Engelbart and Dellweg (1977); Zikmanis et al (1988); Asghari et al (1990), Brian and Craig (1996) reported similar observations.

The production of high percentage of alcohol in this study indicated that, the sugar in the fermented wort did not lead to a decrease in water activity $\left({ }^{a} w\right)$ as it was noticed by Kenyon et al; (1986). Since these substrates were converted to alcohol by fermentation and yield high concentrations, this shows that hydrolysed lignocellulose represents a potential source of renewable energy which was similar to the report of Lynd, 1990; Lebean et al; (1998).

Nutrient (yeast food) that was included in the fermentation media might also accounted for high yield of alcohol. The same trend was observed by Thomas and Ingledew, (1990); Brien and Craig (1996) who reported that in yeast fermentation rate of fermentation and alcohol yields are enhanced with appropriate nutrient in the medium. The production of alcohol from those substrates was also in line with the findings of Belkacemi, et al; (1998) who observed that about 40 $60 \%$ of alcohol was produced after 24 hours with yeast fermentation of forages and agricultural residues such as corn stalks and barley straw.

The high yield of alcohol in this study was also favourably compared with the Dominguez et al; (2000) who reported that about $88.1 \%$ (alcohol by weight) and $72.6 \%$ of alcohol was obtained with yeast fermentation of xylose.

Progressive decreased in alcohol concentrations as the duration of fermentation increases might have resulted in decreased on nutrient value of the fermented wort. In addition, production of toxic byproducts in the medium that could cause death of yeast cells and also serve as inhibitor of cell growth. This observation supports that of Leroi and Ridoux (1993). It also agrees with Zaldivar and Ingram (1999) who observed that both aliphatic and mononuclear organic acids inhibit growth and alcohol production.

The high concentration of sugar obtained in this study was similar to the report of Agboola (2009) who observed the high production of sugar from waste paper and sugar cane wastes. This study has clearly demonstrated the importance of these agricultural chaffs.

\section{CONCLUSION}

The economic importance of this work are: alcohol can serve as source of renewable energy. The use of those selected chaffs assist to solve 
environmental waste problems. The country can save her foreign reserve used in importing alcohol i.e. alcohol serve as source of revenues for both individual and the government.

Despite an enormous and worldwide utilization of different wastes, there are still abundant quantities of agricultural chaffs that could be used more efficiently. Better processing methods that would be more economically profitable are therefore suggested.

\section{ACKNOWLEDGEMENT}

The author thanks Messrs Tunde and Ajayi of Chemistry Department, Kwara State Polytechnic and also staff of Laboratory Section of Chemistry Department, University of Ilorin for assisting in some of the chemical tests in this work.

\section{REFERENCES}

Adeniran, M. K and Adeleye, S., 1994. Comparative Study of the alcoholic product(s) from Potato and Pawpaw. Nigerian Journal of Science. 28, $273-228$

Agboola, F. O., 2006. Experimental Production of Fermentable Sugar from Cellulosic Wastes. Journal of Inter-Disciplinary Science and Technology. 1, (1): $26-30$.

Agboola, F. O., 2009. Production of Reducing Sugar from Waste Paper and Sugar Cane Wastes. Journal of Science and Engineering. 1, (1): 113 -118 .

Ali, S., Sayed, A., Sarker, R. T and Alam, R., 1991. Factors Affecting Cellulose Production by Aspergillus terreus using water hyacinth. World Journal of Microbiology and Biotechnology. 7, $62-66$.

Asghari, A., Bothast, K. J., Doran, J. B and Ingram, I. O., 1990. Ethanol Production from Hemicellulose Hydrolysates of Agricultural residue Using Genetically Engineered Escherichia coli strain I Coll. Journal of Industrial Microbiology. 16, 42 47.

Belkacemi, K., Turcotte, G., de-Halle UX-D and Savoie, P., 1998. Ethanol Production from afex-treated Forages and Agricultural Residues. Applied Biochemi. Biotechnol. $70-72,441-462$.

Brien, D. J. O and Craig, J. C. (Jr)., 1996. Ethanol Production in a Continuous Fermentation/Membrane Pervaporation System. Applied Microbiology and Biotechnology. 44, (6): 700.

Dominguez, J. M., Cao, N., Gong, C. S and Tsao, G. T., 2000. Ethanol Production from Xylose with the Yeast Kpichia stipitis and simultaneous Product recovery by gas stipping using a gas-lift loop fermentor with attach. Side-arm (GLSA). Biotechnol. Bioeng. 67, (3): $336-343$.
Doppelbauer, R., Esternbauer, H., Steiner, W., Lafferty, R. M and Steinmuller, H., 1987. The use of lignocellulosic wastes for production of cellulose by Trichoderma reesei. Applied Microbiology and Biotechnology. 26, $485-495$.

Engelbart, W and Dellweg, H., 1977. Continuous alcoholic fermentation with powdery yeast (Saccharomyces cerevisiae) International Symposium on Alcohol Fuel Technology. Germany. 8.

Gharpuray, M. M., Lee, H and Fan, I. T., 1983. Structural modifications of lignocellulosic by treatments to enhance hydrolysis. Biotechnology and Bioengineering. 21, 131 146.

Kenyon, C. P., Prior, B. A and Van Vunren, H. J. J., 1986. Water relations of ethanol fermentation by $S$. cerevisiae. Enzyme Microbiology Technology. $8,461-464$.

Lebean, T., Jouenne, T and Junter, G. A., 1998. Continuous alcoholic fermentation of glucose/xyclose mixtures by co-immobilized $S$. cerevisiae and Candida Shehatea: Applied Microbiology and Biotechnology. 50, (3): $309-$ 313.

Lee, Y. S., Lee, W. G and Philips, K. I., 1987. The use of cellulosic material for alcohol production. Biotech Letter. 17, (8): 791 - 793.

Lynd, L. R., 1990. Large-scale fuel ethanol from lignocellulose. Applied Biochem. Biotechnology. 24/25, $695-719$.

Lyons, T. P., Kelsall, D. P and Murtagh, J. E., 1995. Use of Cellulosic Feedstocks for Alcohol Production. The Alcohol Textbooks. Nottingham University Press. 37 - 40, 58.

Maheswari, D. K., Jaham, H., Paul, J and Varma, A., 1993. Wheat straw, a potential substrate for cellulose production using Trichoderma reesei.

Marjailmen Anusaloheimno, Maija - Leena Onnela; Merja, E. Pentita., 1997. Regulation of Cellulose gene expression in the filamentous fungus. Richoderma reesei. Applied and Environmental Microbiology. 63, 1298.

Miller, G. L., 1959. Use of Dimitfosalicyclic acid reagent for determination of reducing sugar. Journal of Analytical Chemistry. 31, (3): $426-428$.

Murray, P. R. S., 1974. Test for alcohol. Principles of Organic Chemistry. Heinemann Educational Books Ltd. London, 189.

Palmer, G. H., 1989. Products of Yeast Metabolism; Cereal Science and Technology, Aberdeen University Press, Great Britain. 357. 
Pearson, D. C., 1976. Determination of Alcohol Content. The Chemical Analysis of Foods. Seventh Edition, Churchill Livingstone Edinburgh, London and New York. 329 - 330.

Sanni, A., Awe, F. A and Akinyanju, J. A., 1992. Amylase synthesis in Aspergillus niger grown on cassava peel. Journal of Industrial Microbiology. $10,55-59$.

Thomas, K. C and Ingledew, W. M., 1990. Fuel alcohol production, effect of free amino nitrogen on fermentation of very high gravity wheat mashes. Applied and Environmental Microbiology. 56, $2040-2060$.
Ullah, M. R., Gongoi, N and Baruah, D., 1994. The effect of whitering on fermentation of tea leaf and development of liquid characters of black teas. Journal of Science Food Agriculture. 35, 1142 1147.

Zikmanis, P. B., Kruce, R. V., Auzina, L. P., Margevica, M. V and Beker, M. J., 1988. Intensification of alcoholic fermentation upon dehydration - rehydration of the Saccharomyces cerevisiae. 
APPENDIX I

REFERENCE TABLE 1

\begin{tabular}{|c|c|c|c|}
\hline $\begin{array}{l}\text { Specific gravity at } \\
20^{\circ} \mathrm{C}\end{array}$ & \% Alcohol by Weight & By volume & \%Proof Spirit \\
\hline 0.7904 & 100.00 & 100.00 & 175.35 \\
\hline 0.7936 & 98.98 & 99.31 & $1 / 4.25$ \\
\hline 0.8000 & 96.85 & 98.02 & 171.88 \\
\hline 0.8100 & 93.38 & 95.69 & 167.77 \\
\hline 0.8200 & 89.71 & 93.06 & 163.15 \\
\hline 0.8300 & 85.89 & 90.18 & 158.08 \\
\hline 0.8400 & 81.94 & 87.07 & 152.61 \\
\hline 0.8500 & 77.89 & 83.75 & 146.76 \\
\hline 0.8600 & 73.77 & 80.29 & 140.80 \\
\hline 0.8700 & 69.60 & 76.59 & 134.19 \\
\hline 0.8800 & 65.38 & 72.78 & 127.46 \\
\hline 0.8900 & 61.12 & 68.80 & 120.47 \\
\hline 0.9000 & 56.80 & 64.66 & 113.19 \\
\hline 0.9100 & 52.11 & 60.33 & 105.57 \\
\hline 0.9200 & 47.93 & 55.77 & 97.57 \\
\hline 0.9300 & 43.31 & 50.94 & 89.09 \\
\hline 0.9400 & 38.42 & 45.88 & 79.86 \\
\hline 0.9500 & 33.16 & 39.85 & 69.60 \\
\hline 0.9600 & 27.25 & 33.09 & 57.73 \\
\hline 0.9700 & 20.28 & 24.88 & 43.34 \\
\hline 0.9800 & 12.65 & 15.88 & 27.27 \\
\hline 0.9900 & 5.71 & 17.18 & 12.44 \\
\hline 1.0000 & 0.00 & 0.00 & 0.00 \\
\hline
\end{tabular}

